УДК: $327.7: 341.362 .1$

DOI: $10.24144 / 2218-5348.2019 .1-2(19-20) .230-244$

Мишко Анатолій, студент 2-го курсу магістратури спеціалізачії «Країнознавство» ДВНЗ «Ужсгородський національний університет» Науковий керівник : д.і.н., проф. Вовканич I.I.

\title{
МІЖНАРОДНІ ОРГАНІЗАЦІЇ У БОРОТЬБІ 3 ПІРАТСТВОМ
}

У статті розглядається роль міжнародних організаиій у боротьбі з піратством як злочином міжнародного характеру. Автор визначає актуальність проблеми $і$ наголошуе на необхідності вивчення досвіду боротьби та протидії иьому міжнародному злочину в межах багатонаціонального співробітництва.

Автор приходить до висновку, що вироблення відповідних міжнародних стандартів щзодо піратства, закріплення $\ddot{x}$ у всеосяжному міжнародному договорі, резолюиіях міжнародних організаиій при відповідній волі держав має привести до уніфікащії законодавств держав, однаковому підході до піратства у всьому світі $i$ тим самим до підвищення ефективності протидії піратству.

Ключові слова: піратство, міжнародні організаиії, універсальна юрисдикиія, Конвенція про відкрите море, тероризм, транснаціональна злочинність.

The article examines the role of international organizations in the fight against piracy as an international crime. The author determines the relevance of this problem and emphasizes the need to study the experience of fighting and counteracting this international crime within the framework of multinational cooperation.

The author concludes that the development of relevant international standards of piracy, their enshrining in a comprehensive international treaty, resolutions of international organizations with the appropriate will of states should lead to the unification of state laws, the same approach to piracy around the world and thereby increase the effectiveness of countering piracy.

Keywords: piracy, international organizations, universal jurisdiction, High Seas Convention, terrorism, transnational crime.

Постановка проблеми. Міжнародна злочинність у формі піратства має давню історію, і перехід людства в XXI століття не означає, що воно позбулося старих проблем. На сучасному етапі розвитку людства не тільки 
морське плавання залишається не менш небезпечним, але виникли й інші види піратства, такі, як піратство програмного забезпечення, піратство друкованої продукції, музичне та відеопіратство та інші. В останні роки проблема боротьби з піратством на міжнародному рівні набуває все більшої актуальності. Головним чином це пояснюється активізацією діяльності піратів у багатьох регіонах світу, а також тим фактом, що піратство все тісніше переплітається 3 такими міжнародними явищами, як тероризм, наркотрафік та іншими небезпечними протиправними діяннями.

Актуальність боротьби 3 піратством i практика забезпечення правопорядку, справедливого судового переслідування, розгляду та винесення судових рішень свідчать про необхідність активізації діяльності міжнародних організацій у боротьбі 3 цим злочином міжнародного характеру. Актуальність нашого дослідження полягає у вивченні досвіду боротьби міжнародних організацій 3 піратством та протидії цьому міжнародному злочину в межах багатонаціонального співробітництва.

Ступінь наукового вивчення проблеми. На нашу думку, проблема ролі міжнародних організацій у боротьбі 3 піратством недостатньо досліджена українськими науковцями, які в своїх роботах характеризують лише окремі аспекти цієї проблеми, не завжди враховуючи наявні іншомовні джерела. Серед дослідників, які, вивчаючи піратство, аналізували його певні аспекти, можна виділити Желіховського С. [8] та Леонідову О. [9]. Найбільш грунтовними роботами за темою нашого дослідження можна вважати роботи зарубіжних науковців Чедвіка М.[8], Еллемана Б.А.[9], Джонстона Д.М.[10] та Нуссбаума А. [12].

Об’єктом дослідження є піратство як міжнародний злочин.

Предмет дослідження - боротьба міжнародних організацій з різними видами піратства.

Мета дослідження - здійснити історико-правовий аналіз боротьби міжнародних організацій 3 різними видами піратства та узагальнити цей досвід.

Мета зумовила постановку таких завдань дослідження:

- проаналізувати міжнародно-правові акти та документи міжнародних організацій з питань піратства;

- розглянути діяльність міжнародних організацій у боротьбі 3 піратством;

- розглянути методи протидії піратству.

Виклад основного матеріалу. Розрізняють два основних види співробітництва держав у боротьбі 3 міжнародною злочинністю: укладання міжнародних договорів 3 різних аспектів цієї діяльності та участь держав у міжнародних організаціях, що спеціалізуються на боротьбі зі злочинністю. У міжнародних договорах регулюються питання надання правової допомоги у кримінальних справах, видачі злочинців, передачі засуджених для відбування 
покарання в країни їх громадянства, захисту прав своїх громадян при кримінальному переслідуванні їх в іншій державі, обміну оперативною та правовою інформацією, а також проведення спільних профілактичних заходів. Піратство належить до злочинів, переслідування яких регулюється як законодавством окремих держав, так і міжнародним правом. Це злочин міжнародного характеру, що складається 3 незаконного захоплення, пограбування або потоплення торгових або цивільних суден, вчинені у відкритому морі. До піратства також прирівнюється напад під час війни кораблів, підводних човнів і військових літаків на торгові судна нейтральних країн. Піратські судна, літальні апарати і їх екіпажі не повинні користуватися захистом будь-якої держави. Незалежно від прапора піратські судна можуть бути захоплені кораблями або літальними апаратами, що знаходяться на службі будь-якої країни і мають відповідні повноваження.

\section{ООН у боротьбі 3 піратством}

Стратегічні питання міжнародного співробітництва у сфері боротьби зі злочинністю вирішуються Організацією Об'єднаних Націй. I це невипадково, оскільки злочинність, i, зокрема, піратство, не існують самі по собі, i їх рівень визначається всією системою міжнародних контактів.

Існуючий закон про піратство міститься у статтях 100-107 ЮНКЛОС, які були безпосередньо введені дослівно з тексту Женевської Конвенції про відкрите море 1958 року (ст.14-22) [1]. Визнано, що до моменту розробки Женевської Конвенції про відкрите море піратство вважалося історичним атавізмом і розділи, що стосуються його, були, скоріше, включені в якості історичного обгрунтування, аніж з будь-якої справжньої необхідності. Це стало зрозумілим на засіданні Конференції ООН по морському праву у травні 1956 року, де було зазначено, що проблеми піратства і работоргівлі були винятковими в той час. До розробки Женевської Конвенції було зроблено кілька невдалих спроб кодифікувати звичайне право на піратство jure gentium. Проте ці спроби вважалися законодавчим припущенням (de lege ferenda), а не просто кодифікацією існуючого положення закону.

Женевська Конвенція про відкрите море в значній мірі спиралася на ці попередні спроби кодифікації, а також на підставі прийнятого формулювання закріпила заборону на вилучення каперства з Паризької декларації 1856 року. Однак, перш ніж досліджувати основне визначення закону про піратство, варто відзначити, що стаття 100 ЮНКЛОС вимагає від держав тільки співпрацювати у боротьбі з піратством, при цьому всі інші дії щодо боротьби з піратством є добровільними.

Отже, в 101статті ЮНКЛОС основний злочин піратства jure gentium викладено так: піратство складається з будь-якої з наступних дій:

(a) будь-які незаконні акти насильства або затримання, або будь-який акт депортації, здійснений в особистих цілях екіпажем або пасажирами приватного судна або приватного літака, і спрямований: 
(i) у відкритому морі проти іншого судна або літака або проти осіб або майна на борту такого корабля або літака;

(ii) проти судна, повітряного судна, осіб або майна в місці за межами юрисдикції будь-якої держави;

(b) будь-який акт добровільної участі в експлуатації судна або повітряного судна за наявністю фактів, що це піратський корабель або літак;

(c) будь-який акт підбурювання або навмисного сприяння діям, описаним в підпунктах (a) або (b)[2].

Згідно з Конвенцією, всі держави зобов'язані сприяти викоріненню піратства у відкритому морі і в усіх інших місцях, що знаходяться за межами юрисдикції якої б то не було держави.

Це визначення було джерелом багатьох суперечок. Першим пунктом обговорення було значення фрази «особисті цілі» в підрозділі (а) статті 101. Суть дискусії була в тому, чи виключає ця фраза дії, вчинені за фінансової підтримки держави, або ж animo furandi, як i раніше, $\epsilon$ обов'язковим елементом злочину, таким чином заперечуючи дії, які політично мотивовані як піратство.

Був також спір про те, чи дійсно стаття 101 вимагає наявність двох суден, які будуть задіяні, щоб був доведений акт піратства. Підставою для цього аргументу є концепція 17-го століття, відповідно до якої заколот є формою піратства і карається так само. На думку П.Тасміна, стаття 105 ЮНКЛОС i звичайне піратство jure gentium просто надають право здійснювати державну юрисдикцію в районах, де не існує територіального суверенітету. 3 цієї причини він вважає, що піратство jure gentium не $\epsilon$ злочином універсальної юрисдикції, а злочином, який відбувається за межами суверенної території будь-якої держави i, таким чином, всі держави мають паралельну муніципальну юрисдикцію. Ця точка зору підтверджується історичною та сучасною державною практикою i формулюванням статті 105 ЮНКЛОС. Таким чином, стверджується, що піратство не підпадає під дію міжнародного кримінального права, оскільки юрисдикція і основа юрисдикції є принципово різними[13].

Перший обраний генеральний секретар ООН Трюгве Лі (1946-1952) висловив припущення, що піратство буде відповідною (історичною) паралеллю для судових процесів над нацистами, які залишились живими. На суді над Адольфом Айхманном в Срусалимі у 1961 році, який перебував під універсальною юрисдикцією, Верховний суд Ізраїлю визнав піратські судові процеси природним прецедентом для переслідування нацистів [8].

Одним $з$ основних міжнародних нормативних актів у галузі безпеки мореплавства є Міжнародна конвенція з охорони людського життя на морі 1974 року (СОЛАС-74), прийнята в рамках Міжнародної морської організації (MМO). Спочатку СОЛАС-74 була спрямована на організаційне і технічне оснащення судів, що забезпечує їх безпеку. Пізніше з'явилися заходи 
боротьби 3 піратством, які передбачають міжнародне співробітництво i взаємодію.

Конвенція ООН з морського права 1982 року (набула чинності 16 листопада 1994 року) підтвердила фундаментальні принципи і норми Конвенції про відкрите море. У ст. 101-107, 110-111 майже дослівно відтворюється зміст норм Конвенції про відкрите море ст. 15-23. Морське право дає військовому кораблю будь-якої держави можливість протидіяти піратству у відкритому морі[2].

Відповідно до цього документа, якщо акт піратства здійснений в межах району, на який поширюється суверенітет держави, то інші держави не можуть вжити заходи проти піратів. Це стосується і міжнародних проток, якщо вони знаходяться в зоні територіальних вод держав: право мирного проходу не дає можливості вести боротьбу з піратством, що не передбачає можливості надання допомоги суднам, що піддаються нападу піратів, i затримання піратів з використанням зброї. Військовий корабель зобов'язаний лише проінформувати владу прибережної держави про подію. Пірати користуються цією обставиною, міняючи райони своєї діяльності i прибережні води держав, часто навіть ховаючись від переслідування в чужих територіальних водах.

У Статті 105 Конвенції ООН з морського права 1982 року визначено, що у відкритому морі або в будь-якому іншому місці поза юрисдикцією якої б то не було держави будь-яка держава може захопити піратське судно або судно, захоплене за допомогою піратських дій і знаходиться у владі піратів, заарештувати осіб, які знаходяться на них і захопити майно. При цьому судові установи тієї держави, яка вчинила це захоплення, можуть (але не зобов'язані) виносити постанови про накладення покарань і визначати, які заходи повинні бути вжиті щодо таких суден[2]. Наприклад, напади піратів часто відбуваються в районі Сомалі, але передавати захоплених піратів Сомалі не можна, оскільки в країні вже більше 20 років ведуться міжусобні війни, тому передача піратів у руки сомалійців позбавлена будь-якого сенсу. У зв’язку з цим вся відповідальність за проведення слідчих дій і організацію судового переслідування покладається на ту державу, чий корабель здійснив захоплення піратів. Однак у разі застосування зазначеної вище статті міжнародного договору виникають проблеми процесуального характеру встановлення особи, здійснення перекладу на різні мови в ході перевірки і слідства, збір доказів та отримання правової допомоги інших держав. Потрібно транспортувати підозрюваних, тримати затриманих і засуджених та повертати їх у державу громадянства після відбуття покарання.

Мабуть, з огляду на це деякі держави ухиляються від притягнення піратів до кримінальної відповідальності на своїй території, навіть якщо це дозволяє їх законодавство. Наприклад, Іспанія тільки збирається ввести відповідну статтю в свій кримінальний кодекс. Багато хто прагне передати 
злочинців державам прибережної зони, які мають відповідні правові можливості. У Східній Африці такою державою $є$ тільки Кенія, законодавство якої дозволяе залучати до кримінальної відповідальності піратів - іноземних громадян. Німеччина і Франція передавали судовим органам Кенії осіб, затриманих за вчинення піратства, для цього з Кенією укладені відповідні угоди.

На дипломатичній конференції, що проходила в Римі 31 по 10 березня 1988 року під егідою Міжнародної морської організації (ММО), була прийнята Конвенція про боротьбу з незаконними актами, спрямованими проти безпеки морського судноплавства. Вона застосовується до всіх суден, за винятком військових кораблів; суден, які належать державі або експлуатуються нею в якості військово-допоміжних судів, в митних або поліцейських цілях; або виведені з експлуатації.

Слід зазначити, що, на відміну від Конвенції про відкрите море 1958 року та Конвенції ООН з морського права 1982 року, Конвенція 1988 року спрямована на припинення ширшого кола злочинних посягань, а саме: предметом регулювання в ній названа боротьба з незаконними актами в міжнародному морському судноплавстві; істотна відмінність полягає в сфері застосування: Конвенція 1988 року поширюється на діяння, вчинені в різних категоріях морських просторів - у внутрішніх морських водах, в територіальних водах та у відкритому морі; дія Конвенції не поширюється на літальні апарати; в Конвенції 1988 року інакше, ніж в попередніх міжнародних договорах, вирішено питання про юрисдикцію держав щодо злочинних посягань. Так, при піратстві будь-яка держава має право на припинення (універсальна юрисдикція) актів насильства. Конвенція 1988 закріплює конкуруючу юрисдикцію держав: по-перше, тих, яких стосується скоєний злочин; по-друге, тільки держав-учасниць Конвенції. Загальна для піратства і діянь, передбачених ст. 3 Конвенції 1988 року - юридична кваліфікація їх як міжнародних злочинів. Вони спрямовані і проти національних інтересів, тому цілком виправдано включення в Конвенцію статті 5 , згідно з якою кожна держава-учасниця передбачає покарання за злочини, зазначені в статті 3,3 урахуванням тяжкого характеру цих злочинів[2].

Разом 3 тим Конвенція 1988 року передбачає право, а не обов'язок держав встановлювати юрисдикцію щодо актів піратства, скоєних іноземним громадянином або особою без громадянства.

На Генеральній Асамблеї ООН у вересні 1991 року зазначалося, що зростання злочинності в поєднанні з набуттям транснаціонального характеру ставить під загрозу внутрішню безпеку держав, зазіхає на свободу людини жити без страху, а також може підірвати міжнародні відносини. Все це вимагає створення ефективних міжнародних механізмів і більш тісної співпраці між державами . 


\section{Міжнародна морська організація у боротьбі з піратством}

31983 року проблемами боротьби 3 піратством займається Міжнародна морська організація (ММО), діяльність якої в межах іiі повноважень спрямована на сприяння максимальній безпеці торгівлі та подорожі морським транспортом. Для управління та пом'якшення будь-яких загроз, які потенційно можуть поставити під загрозу морську безпеку, Організація розробляє відповідні правила та інструкції через 5 комітетів:

- Комітет з безпеки на морі (Maritime Safety Committee, MSC КБМ);

- Комітет із захисту морського середовища (Marine Environment Protection Committee, MEPC - K3MC);

- Юридичний комітет (LEG - ЮРКОМ);

- Комітет з технічної співпраці (КТС);

- Комітет з полегшення формальностей судноплавства (FAL).

Міжнародна конвенція ММО з охорони людського життя на морі

(СОЛАС) 1974 року із внесеними змінами містить положення, прийняті для вирішення питань морської безпеки. У розділі XI-2 СОЛАС щодо спеціальних заходів з підвищення безпеки мореплавства міститься Міжнародний Кодекс безпеки суден і портових засобів (International Ship and Port Facility Security Code - ISPS), який набрав чинності 1 липня 2004 року i $\epsilon$ обов'язковим документом для всіх країн-учасниць Конвенції. Метою Кодексу ISPS $є$ забезпечення того, щоб відповідні океанські кораблі та портові споруди держав-членів ММО впроваджували найвищі стандарти безпеки. Розділений на два розділи, Кодекс ISPS містить в обов'язковій частині А детальні вимоги щодо безпеки, якими повинні керуватись уряди, портові адміністрації та судноплавні компанії, а також низку інструкцій щодо виконання цих вимог у необов'язковій частині В[11]. Організація через програму розвитку потенціалу в галузі морської безпеки та технічної співпраці проводить різні національні та регіональні заходи, щоб забезпечити ефективне впровадження Кодексу ISPS державами-членами.

Слід підкреслити, що загроза 3 боку піратства i збройного пограбування кораблів була на порядку денному ММО з початку 1980-х років. Наприкінці 1990 -х і на початку 2000 -х років акцент був зроблений на Південно-Китайському морі, Малакській протоці і Сінгапурі. Починаючи 3 2005 року, ММО зосередилась на піратстві біля узбережжя Сомалі, в Аденській затоці та Індійському океані, і нині реалізує стратегію посилення морської безпеки в Західній і Центральній Африці відповідно до угод про безпеку морського регіону. Організація за підтримки та співпраці 3 судноплавством протягом багатьох років розробила та ухвалила низку антипіратських заходів, які сприяли пом'якшенню негативного впливу піратства у всьому світі. Прикладом може слугувати Кодекс поведінки щодо припинення піратства та озброєного пограбування суден у Західній частині 
Індійського океану та Аденської затоки (Кодекс поведінки Джібуті, 2009 рік), узгоджений між країнами в та навколо Західного Індійського океану, i Кодекс поведінки щодо припинення піратства та збройного пограбування кораблів і незаконної морської діяльності на заході і в центральній Африці в регіоні Гвінейської затоки.

3 того часу через Трастовий фонд ММО Джибуті було розроблено, координовано та впроваджено кілька проєктів та заходів, що здійснюються Групою ММО Секретаріату з впровадження проєкту 3 метою поліпшення регіонального потенціалу для боротьби 3 піратством шляхом сприяння та зміцнення регіонального співробітництва та координації у чотирьох напрямах : навчання, розбудова, правовий та інформаційний обмін.

У червні 2013 в Яунде (Камеруні) був офіційно прийнятий Кодекс поведінки Яунде, розроблений Економічною спільнотою держав Центральної Африки (ECCAS), Економічним співтовариством країн Західної Африки (EКОВАC) та Комісією затоки Гвінеї (GGC) за сприяння ММО відповідно до резолюцій Ради Безпеки ООН 2018 (2011) та 2039 (2012), які висловили стурбованість загрозою того, що піратство і озброєне пограбування у відкритому морі і у Гвінейській затоці створюють загрозу для міжнародного судноплавства, безпеки і економічного розвитку держав регіону. Цей Кодекс, відомий як Кодекс поведінки Яунде, був офіційно схвалений главами держав або їх представниками 25 країн Західної та Центральної Африки, включаючи 13 президентів. Основна мета Кодексу полягає в тому, щоб управляти та значно знижувати негативні наслідки, спричинені піратством, збройним пограбуванням кораблів та іншими незаконними морськими видами діяльності, такими як незаконне, незареєстроване $(\mathrm{HHH})$ рибальство. На нашу думку, стратегія та ініціативи ММО щодо зміцнення морської безпеки в Західній Африці узгоджуються 3 положеннями Кодексу Яунде i допомагають гарантувати адекватність процеса його впровадження, яке має перетворитися на сталий розвиток морського сектора регіону.

Ми вважаємо, що, на відміну від Кодексу поведінки Джібуті, який зосереджується в основному на піратстві, стратегія Західної та Центральної Африки містить комплексні регіональні рамки морської безпеки для боротьби не тільки з піратством і збройним пограбуванням кораблів, але й 3 іншими незаконними морськими діями, такими, як незаконна незареєстрована і нерегульована риболовля та контрабанда наркотиків.

Слід підкреслити, що хоча Кодекс сприяє регіональному співробітництву, він також визнає принципи суверенної рівності, територіальної цілісності держав і невтручання у внутрішні справи інших держав. Крім того, очікується, що успішне впровадження Кодексу поведінки стимулюватиме економічний розвиток країн, які $\epsilon$ iï учасницями, та сприятиме загальному розвитку морського сектору Західної Африки. 
Слід зазначити, що ММО надає допомогу країнам-членам в Гвінейській затоці і навколо неї в перегляді національного законодавства, що передбачає кримінальну відповідальність за піратство, озброєний розбій проти суден і іншу незаконну морську діяльність; розробці і координації відповідних структур і процедур; а також забезпеченні належної підготовки експлуатаційного, технічного та логістичного персоналу[4].

Міжнародною морською організацією також була розроблена низка рекомендацій 3 метою попередження i припинення піратства i збройних пограбувань суден:

- Рекомендації урядам щодо попередження та припинення піратства і збройних пограбувань морських суден (1999 рік);

- Інструкція судновласникам, судноплавним компаніям, капітанам та екіпажам суден щодо попередження та припинення піратства і збройних пограбувань морських суден (2002 рік);

- Директиви для Центрів координації з порятунку на морі (ЦКСМ) (2000 рік);

— Резолюція А. 922 (22) - кодекс поведінки при розслідуванні актів піратства та озброєних пограбувань морських суден;

— Резолюція А. 923 (22) - судна-"примари" і процес реєстрації.

Інформація щодо актів піратства та збройного пограбування проти кораблів доступна для громадськості (за умови реєстрації) в модулі ММО «Піратство та озброєння» в рамках Глобальної інтегрованої інформаційної системи судноплавства Організації (Organization's Global Integrated Shipping Information System - GISIS).

Визнаючи, що бортові інформаційні технології та системи експлуатації суден можуть бути зламані так само легко, як системи на березі, і що такі порушення безпеки можуть завдати значної шкоди безпеці суден, портів, морських об'єктів та інших елементів, морська транспортна система MМО взяла на себе ініціативу щодо підвищення обізнаності промисловості про шляхи подолання та управління морськими кібер-ризиками. Загальною метою є підтримка безпечного судноплавства, яке $є$ операційно стійким до кібер-ризиків.

Крім ММО, розвиток співробітництва країн у сфері боротьби 3 піратством у світі пов'язаний з діяльністю таких міжнародних організацій, як: - Регіональний форум країн АСЕАН - робоча група щодо заходів зміцнення довіри, яка в жовтні 2000 року провела зустріч 3 проблем піратства;

- Симпозіум країн Південно-Китайського моря. Розроблений ним документ "Про врегулювання потенційних конфліктів у ПівденноКитайському морі" містив також пропозиції про "кооперацію між ВМС країн i державних структур регіону" в боротьбі 3 піратством i перевезенням наркотиків; 
- АТРСБ - Азіатсько-Тихоокеанська рада зі співробітництва в сфері безпеки регіонального форуму АCEAH, яка проводить наради двічі на рік. Після зустрічей робочої групи АТБ у 2000 році був виданий "Меморандум про кооперацію в сфері правопорядку і законності на морі", що пропонує в якості першого кроку на шляху боротьби з піратством детальний аналіз відповідних законодавчих актів усіх держав на предмет розбіжностей;

- Регулярні конференції, що організовуються Аналітичним центром 3 проблеми піратства, Інститутом Окасаки (Токіо) спільно 3 органами АСЕАН і національними державними організаціями. У 2000 році були проведені конференції із запрошенням представників командування сил берегової охорони 14 країн АТР і Південно-Східної Азії (від Японії до Індії).

У жовтні 1992 року Міжнародним морським бюро Міжнародної торгової палати за підтримки Міжнародної морської організації ООН в Малайзії в Куала-Лумпурі був створений Регіональний центр 3 проблем піратства, який потім був перейменований в Аналітичний центр 3 проблеми піратства. Він здійснює збір і аналіз інформації в глобальному масштабі, займається розшуком зниклих суден, домагається покарання злочинців i повернення вантажів власникам, виконує цілодобове оповіщення суден про напади піратів і займається організацією допомоги потерпілим суднам.

На нашу думку, мають місце невідповідності i суперечності національних юридичних актів, що стосуються боротьби 3 піратством. Законодавства окремих країн навіть не включають поняття піратства, i розслідування злочинів ведуться по статтях, пов'язаних 3 крадіжками i пограбуваннями. Ми вважаємо, що повинна бути вироблена єдина міжнародна конвенція про покарання за піратство, в якій чітко і вичерпно формулювалося б поняття цього міжнародного злочину, і переслідування за піратство має мати місце незалежно від того, де воно вчинене, а злочинець повинен бути виданий на вимогу. Це дозволить надати нового імпульсу розвитку міжнародної кооперації в цій сфері і розширить коло країн АТР, які ратифікували Римську конвенцію Міжнародної морської організації 1988 року, присвячену протидії незаконній діяльності на морі.

\section{Створення правового захисту проти транснаціональної злочинності}

Одним із складних моментів, який чинні міжнародні договори i резолюції Ради Безпеки ООН не вирішили до кінця, $є$ питання про юрисдикцію, яка застосовується щодо актів піратства та збройного пограбування, а також питання проведення розслідувань і переслідування в судовому порядку осіб, відповідальних за такі діяння.

Крім того, існує і багато інших правових проблем в боротьбі 3 піратством як процесуального, так і фінансового характеру (встановлення особи піратів, збір доказів, транспортування підозрюваних, зміст затриманих 
i засуджених, повернення їх у державу громадянства після відбуття покарання)[5].

Слід зазначити, що для більшості країн поки не вирішена проблема, що робити з захопленими піратами. Наразі існують угоди, укладені США i Європейським Союзом 3 Кенією про передачу ій захоплених піратів для кримінального переслідування, але ці угоди не вирішують всіх проблем, в тому числі для членів Свропейського Союзу. Багатьом країнам доводиться відпускати захоплених піратів. Заходи, що вживаються зараз, не здатні вирішити проблему в цілому. У зв'язку 3 цим слід визнати необхідність комплексної міжнародної відповіді на піратські акти, причому відповіді, заснованої на міжнародному праві i дотриманні загальновизнаних прав людини.

На нашу думку, державам слід вжити комплекс додаткових заходів на міжнародному рівні, спрямованих на ефективне затримання, кримінальне переслідування і засудження будь-яких осіб, винних у морському піратстві, особливо тих, хто організовує і фінансує такі дії.

Генеральні прокурори і міністри юстиції 40 держав, у тому числі 3 низки країн «вісімки», розглянули та опрацювали питання переслідування піратів з використанням механізмів міжнародного правосуддя, i, зокрема, створення міжнародного суду, спрямованого на запобігання злочинних дій піратів. Серед можливих механізмів використання міжнародного правосуддя щодо актів піратства 26 з них активно підтримують пропозицію про створення резолюцією Ради Безпеки ООН міжнародного трибуналу по піратству (за прикладом Міжнародного кримінального трибуналу по Руанді) або регіонального трибуналу за підтримки ООН (за прикладом Спеціального суду по Сьєрра-Леоне i Надзвичайних палат в судах Камбоджі) 3 місцеперебуванням в Кенії або іншій прибережній державі цього регіону.

На думку міжнародних юристів і їх колег, другий варіант найбільш оперативний з точки зору часових i фінансових витрат. При цьому, на їх загальну думку, було б забезпечено дотримання єдиних і високих стандартів правосуддя в кримінальному переслідуванні піратів, у тому числі пов'язаних iз захистом прав людини. Цю пропозицію підтримала і міжнародна юридична громадськість на засіданні Виконавчого комітету Всесвітньої асоціації міжнародного морського права в травні 2009 року в Лондоні. На зустрічі представників парламентів держав «Групи восьми» 16-17 травня 2009 року в Римі пролунали заклики до лідерів «вісімки» дати консолідовану правову відповідь на акти морського піратства.

В середині грудня 2009 року на засіданні Постійного комітету Парламентської асамблеї Ради Європи було одноголосно прийнято рішення про включення цього питання до порядку денного майбутньої сесії асамблеї. 3 урахуванням гостроти проблеми піратства, особливо в районі Африканського Рогу, в цілях забезпечення безпеки, захисту прав і свобод 
людини «Група восьми» підтримала ініціативу італійського головування про прийняття окремої заяви 3 питання про піратство і доручила Римській / Ліонській групі експертів розглянути правові та практичні аспекти цієї проблеми, включаючи питання юрисдикції та можливого використання механізмів міжнародного кримінального правосуддя, а також розробити конкретні пропозиції щодо їх вирішення. Це доручення знайшло своє відображення в підсумковому документі зустрічі. Таким чином, світове співтовариство, усвідомлюючи в повній мірі загрозу піратства робить значні кроки, спрямовані на забезпечення безпеки, захист прав і свобод людини.

Вважаємо за необхідне розглянути питання самооборони суден. Четвертий том довідника «Кращі методи управління боротьбою $з$ піратством біля узбережжя Сомалі і в районі Аравійського моря» (відомий як ВМР4) є чинним авторитетним керівництвом для торгових суден 3 самооборони від піратів. Керівництво випущено і оновлено Міжнародним морським форумом нафтових компаній (OCIMF), консорціумом зацікавлених міжнародних судноплавних i торговельних організацій, включаючи $\in C$, НАТО i Міжнародне морське бюро. Поширюється, головним чином, Центром морської безпеки - Африканський Ріг (MSCHOA), органом планування та координації військово-морських сил $\mathrm{CC}$ (EUNAVFOR). BMP4 рекомендує суднам реєструвати свої рейси через регіон в MSCHOA, оскільки ця реєстрація є ключовим компонентом роботи Міжнародного рекомендованого транзитного коридору (IRTC, маршрут через Аденську затоку, який патрулюється військово-морським флотом). ВМР4 містить розділ під назвою «Заходи самозахисту», в якому викладений список дій, які може виконати торговельне судно для того, щоб не стати мішенню для піратів і бути більш здатним відбити атаку, якщо вона відбудеться. Цей список включає в себе оснащення палуби корабля колючим дротом, оснащення пожежних рукавів для розпилення морської води через борт корабля (для запобігання посадки), створення перешкоди для пострілів і створення «цитаделі», куди може відступити екіпаж в разі, якщо пірати з'являться на борту. Інші неофіційні заходи самооборони, які можна знайти на торгових судах, включають установку манекенів, що зображують озброєних охоронців або стрілянину по піратах.

Слід підкреслити, що в періоди миру у 20 i 21 століттях на торговельних суднах не дозволялося мати зброю. Однак у відповідь на зростання сучасного піратства уряд США змінив ці правила так, що тепер судна під прапором США можуть вступати в групу озброєних приватних охоронців. Берегова охорона США залишає за власниками суден право визначати, чи будуть ці охоронці озброєні.

Міжнародна палата судноплавства (International Chamber of Shipping, ICS) у 2011 році також змінила свою позицію щодо приватних озброєних охоронців, визнавши, що мореплавці повинні мати можливість захищати свої 
кораблі від нападів піратів. Це породило нове покоління приватних охоронних компаній, які проводять навчання членів екіпажу і експлуатують плавучі арсенали для захисту екіпажу і вантажу, що виявилося ефективним у протидії піратським атакам. Використання плаваючих арсеналів у міжнародних водах дозволяє суднам мати зброю в таких водах, не маючи іiі у прибережних водах, де це буде незаконним.

Центр з боротьби з піратством в Індійському океані знаходиться на Сейшельських островах, які стали центральним місцем для міжнародних операцій 3 боротьби 3 піратством. У 2008 році VSOS стала першою уповноваженою компанією щодо забезпечення безпеки на морі, що діяла в регіоні Індійського океану. Після випробувань на безпеку, завершених в кінці 2000-х років, для захисних цілей супер-яхт були розроблені лазерні засліплювачі Вони можуть бути ефективними на відстані до 4 кілометрів (2,5 милі) з ефектами, що переходять від легкої дезорієнтації до виникнення тимчасової сліпоти на більш близькій відстані.

У лютому 2012 року італійські морські піхотинці, які базувалися на танкері Енріке Лексі, нібито обстріляли індійський риболовецький траулер в Кералі, убивши двох $з$ одинадцяти членів екіпажу. Морські піхотинці нібито сплутали рибальське судно 3 піратським. Цей інцидент викликав дипломатичний скандал між Індією та Італією. Команда Енріке була допитана співробітниками індійської поліції в Кочі .

Повідомлялося, що ще один аналогічний інцидент стався в Червоному морі між узбережжями Сомалі і Йемену, в результаті чого загинув єменський рибалка, імовірно, від рук російського загону по захисту суден (VPD) на борту судна під прапором Норвегії.

Проте, незважаючи на те, що розгортання VPD є спірним через ці інциденти, згідно з Associated Press, під час конференції Ради Безпеки ООН по піратству посол США Сьюзан Райс заявила Раді, що жодне судно 3 озброєною охороною не було успішно атаковано піратами, а французький посол Жерар Аро підкреслив, що приватні охоронці не надають стримуючого ефекту, який можуть надати урядові морські патрулі.

Щодо заходів самозахисту, ми поділяємо думку, що кращий захист від піратів - це просто уникати зустрічі з ними. Це може бути досягнуто за допомогою таких інструментів, як радар, або за допомогою спеціалізованих систем, які використовують більш короткі хвилі (адже невеликі човни не завжди уловлюються радаром). Прикладом спеціалізованої системи $\epsilon$ WatchStander. Методом самозахисту може вважатись наявність на судні озброєних приватних охоронців. Крім того, екіпажу може бути наданий курс навчання користування зброєю, i попереджувальні постріли можуть бути зроблені легально в міжнародних водах.

Іншими заходами захисту від піратства $є$ системи зупинки човнів 3 повітряним тиском, які можуть стріляти різними снарядами, що блокують судно, 
впровадження системи вільного проходу і системи захисту на борту судна (наприклад, стінка 3 гарячою водою, електрика на водній стіні, автоматичний пожежний монітор, слизька піна). Судна також можуть намагатися захистити себе, використовуючи свої системи автоматичної ідентифікації (AIS). Кожне судно вагою понад 300 тонн має відповідач, що надає як інформацію про саме судно, так і про його рух. Будь-які несподівані зміни в цій інформації можуть привернути увагу. Раніше ці дані могли бути отримані тільки при наявності сусіднього корабля, що робило окремі кораблі уразливими. Однак нещодавно були запущені спеціальні супутники, які тепер можуть виявляти і ретранслювати ці дані, тому великі кораблі не можуть бути захоплені без виявлення. Це може слугувати стримуючим фактором для спроб або захопити весь корабель, або вкрасти великі частини вантажу на іншому судні, оскільки супровід може бути відправлений набагато швидше.

Слід підкреслити, що в екстрених випадках можуть бути викликані військові кораблі. У деяких районах, зокрема поблизу Сомалі, патрулюючі військово-морські кораблі різних країн можуть перехоплювати судна, які атакують торгові судна. Для патрулювання у небезпечних прибережних водах або зниження вартості патрулювання іноді використовуються роботизовані або дистанційно керовані USV.

\section{Список використаних джерел}

1. Convention on the High Seas 1958 Done at Geneva on 29 April 1958. Entered into force on 30 September 1962. United Nations, Treaty Series, vol. 450, p. 11, p. 82

2. URL: http://legal.un.org/ilc/texts/instruments/english/conventions/8

3. U.N. Convention on the Law of the Sea art. 101, opened for signature Dec. 10, 1982, 1833 U.N.T.S. 397 (entered into force Nov. 16, 1994)

4. URL: https://www.un.org/depts/los/piracy/piracy_documents.htm

5. United Nations Documents on Piracy URL: https://www.un.org /depts/los/piracy/piracy_documents.html

6. West and Central Africa Regional Agreements and Information Sharing URL: http://www.imo.org/en/OurWork/Security/WestAfrica/Pages/ Codeof-Conduct-against-illicit-maritime-activity.aspx

7. Есаков Г .А. Кримінальне право зарубіжних країн. М .: ПРІОР, 2009. $246 \mathrm{c}$.

8. Желіховський С. Морське піратство як загроза міжнародній безпеці // Зовнішні справи. 2013. № 10. С. 54-56.

9. Леонідова О. Історія міжнародно-правової боротьби із піратством//Актуальні проблеми міжнародних відносин. Випуск 90 (Частина I), 2010. С.160-162.

10. Chadwick M. The prosecution of pirates was a model for today's system of international justice/ Mark Chadwick URL: https://theconversation.com/ 
the-prosecution-of-pirates-was-a-model-for-todays-system-of-international-justice109169

11. Elleman B. A. Piracy and Maritime Crime: Historical and Modern Case Studies Paperback: Create Space Independent Publishing/ Elleman Bruce A., Andrew Forbes. Platform. November 17, 2014. 272p.

12. Johnston D. M. The Historical Foundations of World Order: The Tower and the Arena. Boston: Martinus Publishers, 2008. 401p.

13. Maritime Security and Piracy URL: http://www.imo.org/en/ OurWork/Security/Pages/ MaritimeSecurity.aspx

14. Nussbaum A. A Concise History of the Law of Nations. New York: The Macmillan Company, 1947. $361 \mathrm{p}$.

15. Paige Tasmin. Piracy and Universal Jurisdiction// Macquarie Law Journal. 2013, volume12. pp. 131-154.

\section{REFERENCES}

7. Esakov G .A. Kry`minal’ne pravo zarubizhny`x krayin. M.: PRIOR, 2009. $246 \mathrm{c}$.

8. Zhelixovs `ky j S. Mors `ke piratstvo yak zagroza mizhnarodnij bezpeci // Zovnishni spravy`. 2013. N. 10. S. 54-56.

9. Leonidova O. Istoriya mizhnarodno-pravovoyi borot 'by` iz piratstvom //Aktual`ni problemy` mizhnarodny`x vidnosy`n. Vy`pusk 90 (Chasty`na I), 2010. S.160-162. 